\title{
Differential modulation of NMDA and AMPA receptors by cellular prion protein and copper ions
}

\author{
Sun Huang ${ }^{1,3,4}$, Lina Chen ${ }^{1,3,4}$, Chris Bladen ${ }^{1,3,4}$, Peter K. Stys $s^{2,3}$ and Gerald W. Zamponi ${ }^{1,3,4^{*}}$ (D)
}

\begin{abstract}
N-Methyl-D-aspartate receptors (NMDARs) and a-amino-3-hydroxy-5-methyl-4-isoxazolepropionic acid receptors (AMPARs) are two major types of ionotropic glutamate receptors involved in synaptic transmission. However, excessive activity of these receptors can be cytotoxic and thus their function must be precisely controlled. We have previously reported that NMDA receptor activity is dysregulated following genetic knockout of cellular prion protein $\left(\operatorname{PrP}^{C}\right)$, and that $\operatorname{PrP}^{C}$ regulation of NMDA receptors is copper-dependent. Here, we employed electrophysiological methods to study NMDAR and AMPAR currents of cultured hippocampal neurons from PrPC overexpresser mice. We show that NMDA receptor current amplitude and kinetics are differentially modulated by overexpression of human or mouse PrPC . By contrast, AMPA receptor activity was unaffected. Nonetheless, AMPA receptor activity was modulated by copper ions in a manner similar to what we previously reported for NMDA receptors. Taken together, our findings reveal that AMPA and NMDA receptors are differentially regulated by PrPC, but share common modulation by copper ions.
\end{abstract}

Keywords: NMDA receptor, AMPA receptor, Cellular prion protein, Knock-in mice, Whole-cell patch clamp, Hippocampal neurons, CNS disorders, Copper

\section{Introduction}

Glutamate is the principal excitatory neurotransmitter in the mammalian central nervous system (CNS) and interacts with both metabotropic and ionotropic receptors [1] to trigger and modulate postsynaptic responses. Both NMDA and AMPA receptors are critical mediators of synaptic plasticity [2-7], whereas dysregulation of these receptors contributes to neurodegeneration in a wide range of disorders, including stroke and Alzheimer's disease [8-14]. We have previously shown that cellular prion protein $\left(\mathrm{PrP}^{\mathrm{C}}\right)$ physically interacts with, and regulates NMDA receptor function $[15,16]$. In hippocampal neurons, knockout of $\operatorname{PrP}^{\mathrm{C}}$ leads to augmented NMDA receptor activity and a slowing of deactivation kinetics [17], potentially underpinning neurotoxicity and neurodegeneration. $\mathrm{PrP}^{\mathrm{C}}$ is widely expressed across the nervous

\footnotetext{
* Correspondence: zamponi@ucalgary.ca

${ }^{1}$ Department of Physiology and Pharmacology, University of Calgary, Calgary, $A B$, Canada

${ }^{3}$ Hotchkiss Brain Institute, University of Calgary, Calgary, AB, Canada

Full list of author information is available at the end of the article
}

system and features four to five octapeptide repeats (depending on the species) in the unstructured $\mathrm{N}$-terminal [18] which contain histidine residues that form multiple copper binding sites with varying copper affinities [19]. Chelation of copper ions with bathocuproine disulfonate (BCS) [20] results in increased NMDA receptor peak current amplitude, and a slowing of desensitization kinetics, leading to a large steady state NMDA current that may contribute to cytotoxicity. Here, we build on our previous findings to examine the effects of overexpressing $\operatorname{PrP}^{\mathrm{C}}$ not only on NMDA receptors, but also on AMPA receptor activity. We show that overexpression of mouse and human $\operatorname{PrP}^{\mathrm{C}}$ in hippocampal pyramidal cells resulted in altered NMDA receptor current amplitude and desensitization kinetics. AMPA receptor activity, on the other hand, does not appear to be affected by $\operatorname{PrP}^{\mathrm{C}}$. AMPA receptors, however, are sensitive to copper chelation such that removal of copper ions resulted in increased steady state currents. Collectively, our data indicate distinct regulation of NMDA and

(c) The Author(s). 2018 Open Access This article is distributed under the terms of the Creative Commons Attribution 4.0 International License (http://creativecommons.org/licenses/by/4.0/), which permits unrestricted use, distribution, and 
AMPA receptors by $\operatorname{PrP}^{\mathrm{C}}$, whereas both receptor types are similarly regulated by copper ions.

\section{Materials and methods Neuronal primary culture}

Wild-type C57 mice were purchased from Charles River and maintained in compliance with the University of Calgary Animal Care and Use policies. Knock-in mice Tg650 (with human cellular prion protein) were provided by the French National Institute for Agricultural Research and Tga20 mice (with murine cellular prion protein) were provided by Dr. Frank Jirik and bred in house. Both mouse lines are originally from the European Mouse Mutant Archive. P0-P1 pups were used to prepare the hippocampal neurons for primary culture. All animal experiments were conducted with the approval of the animal care committee of the University of Calgary.

\section{Electrophysiology}

Whole-cell voltage-clamp recordings were performed at room temperature on hippocampal pyramidal neurons after 10-15 days in culture, using an Axopatch 200B amplifier (Axon Instruments). The holding potential was $-60 \mathrm{mV}$ throughout. The external solution contained $140 \mathrm{mM} \mathrm{NaCl}, 5 \mathrm{mM} \mathrm{KCl}, 1 \mathrm{mM} \mathrm{CaCl} 2,25 \mathrm{mM}$ Hepes, and $33 \mathrm{mM}$ D-Glucose, $\mathrm{pH}$ was adjusted to 7.4 with $\mathrm{NaOH}$. To obtain NMDA currents, the external solution was supplemented with $15 \mu \mathrm{M}$ 2,3-dihydroxy-6nitro-7-sulfamoyl-benzo[f]quinoxaline (NBQX, from Tocris Bioscience), $100 \mu \mathrm{M}$ picrotoxin (PTX), $1 \mu \mathrm{M}$ tetrodotoxin (TTX, from Tocris Bioscience), $500 \mathrm{nM}$ $\mathrm{CuSO}_{4}$ (to standardize $\left[\mathrm{Cu}^{2+}\right]$ in external solution), and different concentrations of glycine as indicated. To obtain AMPA currents, the external solution was supplemented with $100 \mu \mathrm{M}$ PTX, $1 \mu \mathrm{M}$ TTX and $500 \mathrm{nM}$ $\mathrm{CuSO}_{4}$. The internal pipette solution was composed of $140 \mathrm{mM} \mathrm{CsCl}, 11 \mathrm{mM}$ EGTA, $1 \mathrm{mM} \mathrm{CaCl} 2,2 \mathrm{mM}$ $\mathrm{MgCl}_{2}$, and $10 \mathrm{mM}$ Hepes, $\mathrm{pH}$ was adjusted to 7.3 with $\mathrm{CsOH}$. The internal solution was supplemented with $4 \mathrm{mM} \mathrm{K} \mathrm{K}_{2}$ ATP and $0.6 \mathrm{mM}$ GTP, added immediately before use. Superfusion was performed by a rapid microperfusion system (EVH-9, from Biologic Science Instruments) to achieve fast switching of solutions. The perfusion tip was positioned a few hundred micrometers from the cell and kept as constant as possible during the experiments. The solution exchange was computer controlled by a Digidata $1322 \mathrm{~A}$ interface (Molecular Devices). NMDA receptor-mediated currents were evoked by application of $500 \mu \mathrm{M}$ NMDA (Tocris Bioscience) and AMPA receptor-mediated currents were evoked by application of $100 \mu \mathrm{M}$ AMPA (Tocris Bioscience). In a typical 30-s interval experiment, first external solution without agonist was applied to create a stable baseline, then the neuron was perfused with external solution with ligand for $7 \mathrm{~s}$ to evoke the currents, after reaching a stable state the channel was switched back to solution without ligand. The steady-state current was determined as the non-desensitizing current amplitude at the end of a 7-s application.

\section{Data analysis and statistics}

Data were analyzed with either One-Way ANOVA with a Bonferroni post hoc test or via paired t-tests as appropriate. All error bars are S.E.M., and asterisks and number symbols denote statistical significance at the 0.05 , 0,01 , or 0.001 levels, respectively for one, two or three symbols.

\section{Results}

We employed whole-cell voltage-clamp recordings to study the hippocampal neurons in C57 wild type, as well as Tg650 and Tga20 $\mathrm{PrP}^{\mathrm{C}}$ knock-in mice over-expressing human and murine cellular prion protein, respectively.

\section{Human and mouse PrPC differentially affects NMDA current activity}

NMDA receptors require the co-agonist glycine for channel activation, in addition to the primary agonist glutamate or NMDA, with increasing glycine concentrations resulting in both an increase in whole cell NMDA current amplitude, and a slowing of desensitization kinetics. Figure 1a depicts typical agonist-evoked NMDA currents in the presence of $1 \mu \mathrm{M}$ glycine. As evident from the raw current data, the overexpression of mouse $\operatorname{PrP}^{C}$ leads to increased desensitization compared to those observed in C57 mouse neurons, as reflected in a decrease in steady state current. Overexpression of human $\mathrm{PrP}^{\mathrm{C}}$ produced the opposite effect leading to less desensitization of NMDA currents in the prolonged presence of agonist. Figure $1 \mathrm{~b}$ examines steady state (i.e. non desensitizing current) of the receptors for the three mouse lines in response to a range of glycine concentrations. Here, the steady state NMDA current was normalized to the peak current amplitude, and therefore values close to 1 correspond to completely non-desensitizing currents, whereas zero reflects complete desensitization. As evident from the figure, NMDA receptors in Tg650 neurons showed increased glycine sensitivity and much less complete desensitization compared to Tga20 or wild type mice. The NMDA receptor peak current amplitude of Tga20 and wild type mice was similar across the entire range of glycine concentrations, whereas that of Tg650 was augmented at lower glycine concentrations, suggesting an overall enhancement of glycine sensitivity of NMDA receptors co-expressed with an excess of human $\operatorname{PrP}^{\mathrm{C}}$ (Fig. 1c). The area under the current traces, representing the total charge admitted into the cell during the period of agonist application, is a combined 


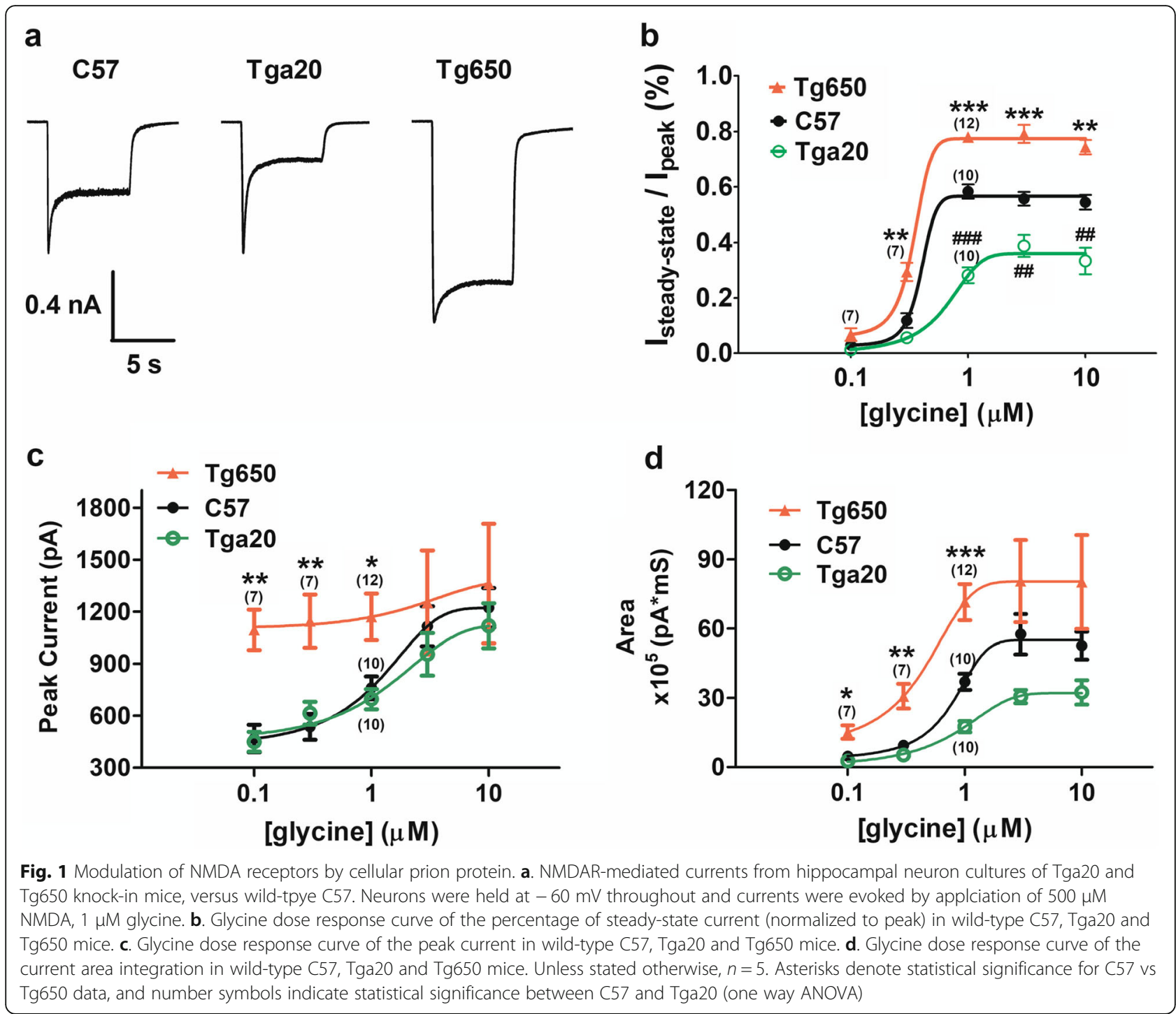

measure of peak and steady-state currents. As shown in Fig. 1d, the pattern across the three strains at various glycine concentrations paralleled that of the steady-state currents in Fig. 1b. NMDA receptors from Tg650 mouse neurons had a higher sensitivity to glycine and admitted more charge during the period of agonist application, compared to WT neurons. The opposite was true for Tga20 neurons.

AMPARs are weakly regulated by $\mathrm{PrP}^{\mathrm{C}}$

We then performed analogous experiments on AMPA receptors expressed in Tga20, Tg650 and C57 mouse hippocampal neurons. Unlike NMDA receptors, no co-application of glycine was needed. As evident from Fig. 2, overexpression of either mouse or human $\operatorname{PrP}^{C}$ did not strongly affect desensitization kinetics (Fig. 2a, b), nor did it alter peak current amplitude or overall cation influx (Fig. 2b-d). Only AMPA receptors from Tg650 neurons exhibited a modest but significantly increased steady-state current. These data indicate that AMPA receptors are not as strongly regulated by overexpression of different $\operatorname{PrP}^{\mathrm{C}}$ species compared to what is seen with NMDA currents.

\section{AMPA receptor activity is copper dependent}

Previous work revealed both $\operatorname{PrP}^{\mathrm{C}}$-dependent and independent regulation of NMDA receptors by copper ions $[15,16]$. To determine if copper ions are also able to regulate AMPA receptor activity, we performed experiments where extracellular copper was clamped at $10 \mu \mathrm{M}$, and then chelated by an excess of $20 \mu \mathrm{M}$ BCS which is highly selective for this metal and exhibits an affinity in the attomolar range (thus allowing us to compare the effects of $10 \mu \mathrm{M}$ copper to a nominally copper free condition). Figure $3 \mathrm{a}$ and $\mathrm{b}$ shows that copper chelation results in an increase in steady-state AMPA 


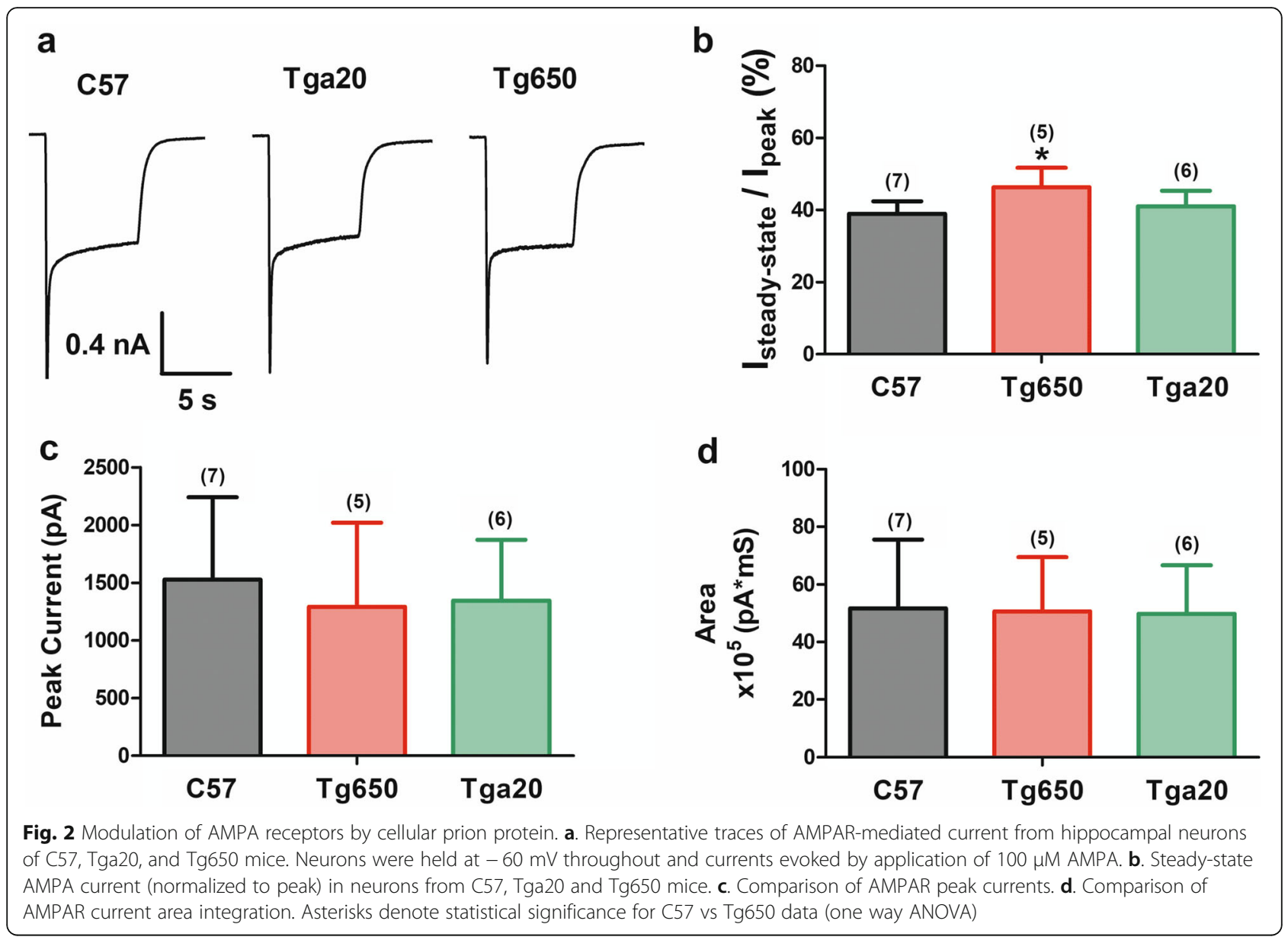

current for both $\operatorname{Tg} 650$ and wild type neurons, to similar levels (as a ratio in comparison with copper-replete traces) across the three mouse lines. These data also unmask a small difference in AMPA current desensitization in $10 \mu \mathrm{M}$ copper between $\mathrm{C} 57$ and $\operatorname{Tg} 650$ neurons, with the latter exhibiting a modest but significantly greater steady-state current (Fig. 3b). There was only a small effect of copper chelation on peak current amplitude and total cation entry in the two experimental conditions that appeared to be somewhat larger in Tg650 neurons (Fig. 3c and d). Overall, these data indicate that copper has the ability to regulate AMPA receptors, in a manner that is qualitatively similar to what we had reported previously for NMDA receptors.

\section{Discussion}

Here we report that two types of ionotropic glutamate receptors are differentially modulated by overexpression of either mouse or human $\operatorname{PrP}^{\mathrm{C}}$. Additionally, the kinetics of both receptors are regulated by copper ions. This work builds on two previous studies from our groups. The first study reported the effects of depleting $\operatorname{PrP}^{\mathrm{C}}$ on whole cell NMDA currents in mouse hippocampal neurons. These early findings revealed that the absence of $\operatorname{PrP}^{C}$ slowed NMDA receptor deactivation and drastically augmented the magnitude of NMDA receptor mediated synaptic events, whereas AMPA receptor-mediated events showed a small enhancement of current amplitude, but no change in rise or decay times [17]. In a second study, we examined the effects of copper chelation on NMDA receptor currents in rat and in C57 mouse hippocampal neurons. These experiments revealed an augmentation of peak current amplitude and steady state NMDA current upon copper chelation. They also showed that NMDA currents in $\operatorname{PrP}^{C}$ null mouse neurons exhibited a leftward shift in the glycine dose-response of steady state current, so that lower levels of ambient glycine were required for receptor activation. Here, (see Fig. 1b) overexpression of mouse $\mathrm{PrP}^{\mathrm{C}}$ (roughly six-fold in Tga20 mice compared to C57) mediated the opposite effect where a rightward shift in the glycine response curve and a reduced plateau of steady state current reflected a greater desensitization of NMDA currents. These findings are consistent with an overall protective role of $\mathrm{PrP}^{\mathrm{C}}$ that 

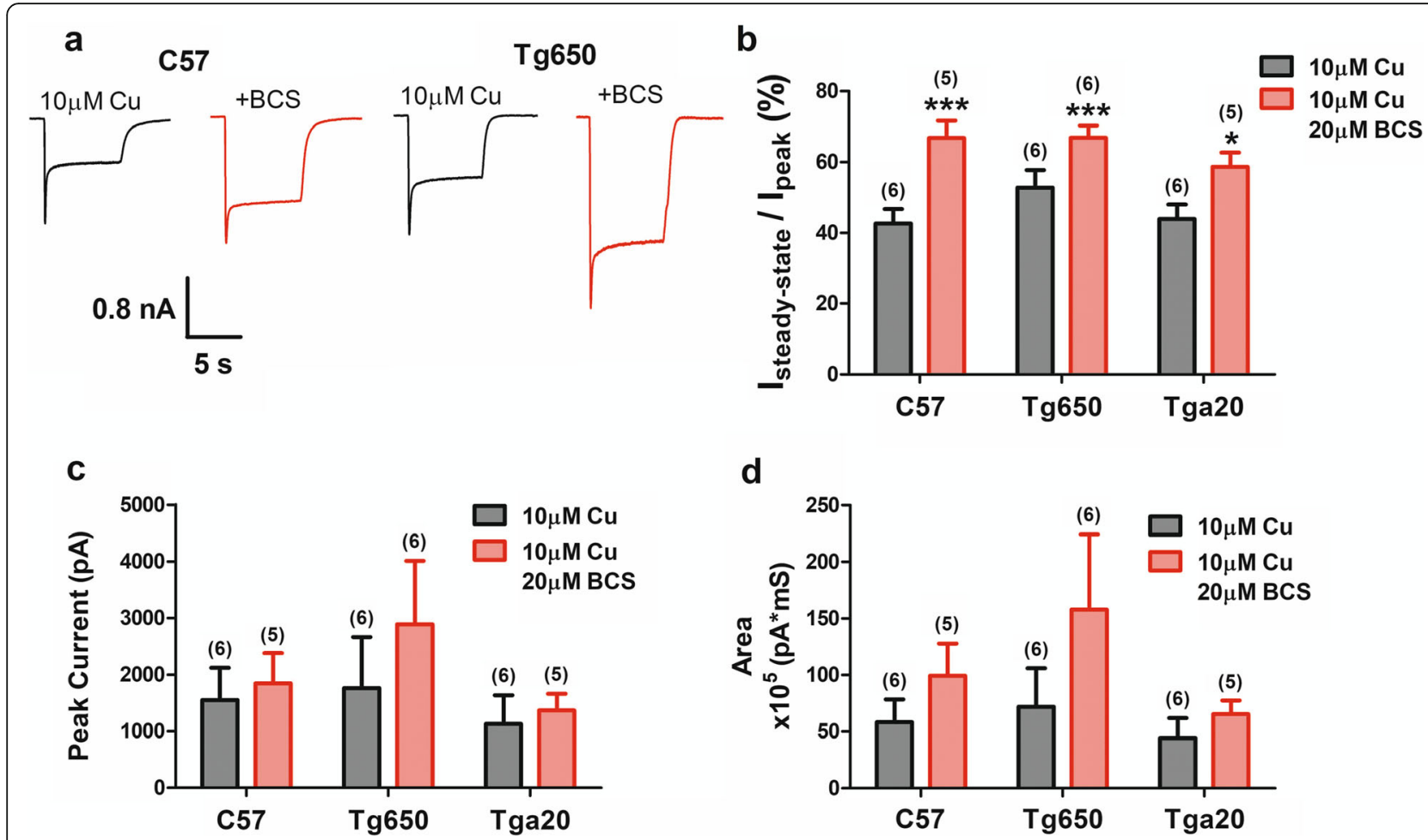

Fig. 3 Modulation of AMPA receptors by copper ions. a. sample traces of AMPA receptor currents in C57 and Tg650 neurons in either $10 \mu \mathrm{M}$ copper, or $10 \mu \mathrm{M}$ copper $+20 \mu \mathrm{M}$ BCS (nominally zero free copper). b. Steady state AMPA current (normalized to peak) obtained from C57, Tga20 and Tg650 mouse hippocampal neurons in the presence of $10 \mu \mathrm{M}$ copper, or $10 \mu \mathrm{M}$ copper plus $20 \mu \mathrm{M}$ BCS. c. Comparison of peak currents before and after BCS application as in panel $\mathbf{a}$. $\mathbf{d}$. Integrated current area under the conditions of panels $\mathbf{a}$ and $\mathbf{b}$. Asterisks denote statistical significance (paired t-test)

could function to reduce overall cation flux through these receptors and subsequent excitotoxicity. Remarkably, overexpression of human $\operatorname{PrP}^{\mathrm{C}}$ (roughly six fold in $\mathrm{Tg} 650$ mice over $\operatorname{PrP}^{C}$ levels in C57) [21] had an opposite effect compared to mouse $\operatorname{PrP}^{\mathrm{C}}$, resulting in increased sensitivity to glycine of NMDA receptor-mediated currents. In some ways, our data with $\operatorname{Tg} 650$ neurons are reminiscent of what we had observed previously with $\mathrm{PrP}^{\mathrm{C}}$ null mice, suggesting that either human $\operatorname{PrP}^{\mathrm{C}}$ cannot effectively interact with mouse NMDA receptors, or that human $\operatorname{PrP}^{C}$ does not bear the ability to functionally regulate receptor desensitization. Human and mouse $\operatorname{PrP}^{\mathrm{C}}$ are approximately $90 \%$ identical at the amino acid levels, with minor differences occurring throughout the entire length of the protein (including small deletions and insertions). It is known that even single amino acid changes can affect the folding and misfolding of $\operatorname{PrP}^{\mathrm{C}}$ and it is possible that the NMDA receptor is differentially sensitive to the conformation adopted by human and mouse $\operatorname{PrP}^{\mathrm{C}}$. This could explain the late neurodegeneration that occurs spontaneously in aged $\operatorname{Tg} 650$ mice [22], resulting from a subtle but chronic excitotoxicity and excessive calcium loads experienced by these neurons over time. Moreover, these observations support the notion that misfolded $\operatorname{PrP}$ as occurs in a variety of prionopathies, could become less competent in its ability to regulate NMDA receptor kinetics, likewise leading to excitotoxicity and neuronal death.

In contrast to NMDA receptors, AMPA receptors do not appear to be strongly regulated by overexpression of mouse or human $\operatorname{PrP}^{\mathrm{C}}$, and these data are consistent with our earlier synaptic work in $\operatorname{PrP}^{\mathrm{C}}$ null mouse neurons that showed only a small effect on miniature synaptic events in hippocampal cultures [17]. This suggests that $\operatorname{PrP}^{\mathrm{C}}$ may either not be able to interact with AMPA receptors at all, or alternatively, that the interactions may simply not produce potent functional effects. The observation that there was a small but statistically significant effect on steady state current in Tg650 neurons may support the latter possibility. There was, however, a potent effect of copper chelation on steady-state current amplitude. It is unclear whether this effect is mediated by indirect interactions via the copper binding sites on $\operatorname{PrP}^{\mathrm{C}}$, other interacting copper-binding proteins, or by copper ions interacting with the pore of the receptor directly. Indeed, we note that copper ions are able to speed desensitization and inhibit peak current amplitude of NMDA currents in $\operatorname{PrP}^{C}$ null mice, consistent with open channel block, and a similar mechanism may be at play 
here with AMPA receptors. Acute effects of copper on AMPA-mediated synaptic events have been reported in the literature, and are consistent with our present findings [23].

Altogether, our findings reveal differences in the regulation of AMPA and NMDA receptor by cellular prion protein. In the context of prion disease, synaptic deficits due to misfolding of $\operatorname{PrP}^{\mathrm{C}}$ are thus more likely to arise from dysregulation of NMDA receptors than AMPA receptors. Our data also reinforce the central role of copper ions as potent regulators of two major excitatory receptors in the CNS.

\section{Abbreviations}

AMPA: a-amino-3-hydroxy-5-methyl-4-isoxazolepropionic acid BCS: Bathocuproine disulfonate; NMDA: N-Methyl-D Aspartate; PrP ${ }^{C}$ : Cellular prion protein; PTX: Picrotoxin; TTX: Tetrodotoxin

\section{Acknowledgements}

We thank Drs. Vincent Beringue and Frank Jirik for providing us with access to transgenic mice.

\section{Funding}

This work was supported by the Alberta Prion Research Institute. GWZ and PKS are Canada Research Chairs.

\section{Availability of data and materials}

All data generated or analysed during this study are included in this published article.

\section{Authors' contributions}

SH, LC and CB performed experiments. GWZ and PKS conceived and supervised the study. SH, GWZ and PKS wrote the manuscript. All authors read and approved the final manuscript.

\section{Ethics approval and consent to participate}

This study was approved by the University of Calgary's animal care committee.

\section{Consent for publication}

Not applicable

\section{Competing interests}

The authors declare that they have no competing interests.

\section{Publisher's Note}

Springer Nature remains neutral with regard to jurisdictional claims in published maps and institutional affiliations.

\section{Author details}

'Department of Physiology and Pharmacology, University of Calgary, Calgary, $A B$, Canada. ${ }^{2}$ Department of Clinical Neurosciences, University of Calgary, Calgary, AB, Canada. ${ }^{3}$ Hotchkiss Brain Institute, University of Calgary, Calgary, AB, Canada. ${ }^{4}$ Alberta Children's Hospital Research Institute, University of Calgary, Calgary, AB, Canada.

Received: 17 September 2018 Accepted: 14 October 2018

Published online: 25 October 2018

\section{References}

1. McBain CJ, Mayer ML. N-methyl-D-aspartic acid receptor structure and function. Physiol Rev. 1994;74:723-60.

2. Herron CE, Lester RA, Coan EJ, Collingridge GL. Frequency-dependent involvement of NMDA receptors in the hippocampus: a novel synaptic mechanism. Nature. 1986;322:265-8.

3. Collingridge G. Synaptic plasticity. The role of NMDA receptors in learning and memory. Nature. 1987;330:604-5.
4. MacDonald JF, Jackson MF, Beazely MA. Hippocampal long-term synaptic plasticity and signal amplification of NMDA receptors. Crit Rev Neurobiol. 2006;18:71-84.

5. Traynelis SF, Wollmuth LP, et al. Glutamate receptor ion channels: structure, regulation, and function. Pharmacol Rev. 2010;62:405-96.

6. Chater TE, Goda Y. The role of AMPA receptors in postsynaptic mechanisms of synaptic plasticity. Front Cell Neurosci. 2014;8:401.

7. Henley JM, Wilkinson KA. Synaptic AMPA receptor composition in development, plasticity and disease. Nat Rev Neurosci. 2016;17:337-50.

8. Lipton SA, Rosenberg PA. Excitatory amino acids as a final common pathway for neurologic disorders. N Engl J Med. 1994;330:613-22.

9. Kalia LV, Kalia SK, Salter MW. NMDA receptors in clinical neurology: excitatory times ahead. Lancet Neurol. 2008;7:742-55.

10. Palop JJ, Mucke L. Amyloid- $\beta$-induced neuronal dysfunction in Alzheimer's disease: from synapses toward neural networks. Nat Neurosci. 2010;13:812-8.

11. Kwak S, Weiss JH. Calcium-permeable AMPA channels in neurodegenerative disease and ischemia. Curr Opin Neurobiol. 2006;16:281-7.

12. Weiss JH. Ca permeable AMPA channels in diseases of the nervous system. Front Mol Neurosci. 2011;4:42.

13. Rogawski MA. AMPA receptors as a molecular target in epilepsy therapy Acta Neurol Scand Suppl. 2013;197:9-18.

14. Bowie D. lonotropic glutamate receptors \& CNS disorders. CNS Neurol Disord Drug Targets. 2008;2:129-43.

15. You $\mathrm{H}$, et al. $A \beta$ damages neurons by altering copper-dependent prion protein regulation of NMDA receptors. Proc Natl Acad Sci U S A. 2012;109: 1737-42.

16. Stys PK, You H, Zamponi GW. Copper-dependent regulation of NMDA receptors by cellular prion protein: implications for neurodegenerative disorders. J Physiol. 2012;590(6):1357-68.

17. Khosravani, et al. Prion protein attenuates excitotoxicity by inhibiting NMDA receptors. J Cell Biol. 2008;181(3):551-65.

18. Riesner D. Biochemistry and structure of PrPc and PrPsc. Br Med Bull. 2003; $66: 21-33$.

19. Millhauser GL. Copper and the prion protein: methods, structures, function, and disease. Annu Rev Phys Chem. 2007:58:299-320.

20. Mohindru A, Fisher JM, Rabinovitz M. Bathocuproine sulphonate: a tissue culture-compatible indicator of copper-mediated toxicity. Nature. 1983; 303(5912):64-5.

21. Vincent, et al. Prominent and persistent Extraneural infection in human PrP transgenic mice infected with variant CJD. PLoS One. 2008;3(1):e1419.

22. Westaway D, et al. Degeneration of skeletal muscle, peripheral nerves, and the central nervous system in transgenic mice overexpressing wild-type prion proteins. Cell. 1994;76(1):117-29.

23. Peters, et al. Biphasic effects of copper on neurotransmission in rat hippocampal neurons. J Neurochem. 2011;119(1):78-88.

Ready to submit your research? Choose BMC and benefit from:

- fast, convenient online submission

- thorough peer review by experienced researchers in your field

- rapid publication on acceptance

- support for research data, including large and complex data types

- gold Open Access which fosters wider collaboration and increased citations

- maximum visibility for your research: over $100 \mathrm{M}$ website views per year

At $B M C$, research is always in progress.

Learn more biomedcentral.com/submission 